\title{
Nitric Oxide-Producing Islet Cells Modulate the Release of Sensory Neuropeptides in the Rat Substantia Gelatinosa
}

\author{
Patrizia Aimar, ${ }^{1}$ Lucia Pasti, ${ }^{2}$ Giorgio Carmignoto,, ${ }^{2}$ and Adalberto Merighi ${ }^{1}$ \\ ${ }^{1}$ Dipartimento di Morfofisiologia Veterinaria, Università degli Studi di Torino, I-10126 Torino, Italy, and 2Dipartimento di \\ Scienze Biomediche Sperimentali, Università degli Studi di Padova, I-3531, and Centro per lo Studio delle Biomembrane \\ del Consiglio Nazionale delle Ricerche, Padova, Italy, European Union
}

The substantia gelatinosa of the spinal cord (lamina II) is the major site of integration for nociceptive information. Activation of NMDA glutamate receptor, production of nitric oxide (NO), and enhanced release of substance $P$ and calcitonin generelated peptide (CGRP) from primary afferents are key events in pain perception and central hyperexcitability. By combining reduced nicotinamide adenine dinucleotide phosphate (NADPH) diaphorase histochemistry for NO-producing neurons with immunogold labeling for substance P, CGRP, and glutamate, we show that (1) NO-producing neurons in lamina $I_{i}$ are islet cells; (2) these neurons rarely form synapses onto peptideimmunoreactive profiles; and (3) NADPH diaphorase-positive dendrites are often in close spatial relationship with peptidecontaining terminals and are observed at the periphery of type II glomeruli showing glutamate-immunoreactive central endings. By means of confocal fluorescent microscopy in acute spinal cord slices loaded with the $\mathrm{Ca}^{2+}$ indicator Indo-1, we also demonstrate that (1) NMDA evokes a substantial $\left[\mathrm{Ca}^{2+}\right]_{\mathrm{i}}$ increase in a subpopulation of neurons in laminae I-II, with morphological features similar to those of islet cells; (2) a different neuronal population in laminae $\mathrm{I}-\mathrm{II}_{\mathrm{O}}$, unresponsive to NMDA, displays a significant $\left[\mathrm{Ca}^{2+}\right]_{\mathrm{i}}$ increase after slice perfusion with either substance $\mathrm{P}$ and the $\mathrm{NO}$ donor 3morpholinosydnonimine (SIN-1); and (3) the responses to both substance $\mathrm{P}$ and $\mathrm{SIN}-1$ are either abolished or significantly inhibited by the $\mathrm{NK}_{1}$ receptor antagonist sendide. These results provide compelling evidence that glutamate released at type II glomeruli triggers the production of $\mathrm{NO}$ in islet cells within lamina $\|_{i}$ after NMDA receptor activation. The release of substance $P$ from primary afferents triggered by newly synthesized NO may play a crucial role in the cellular mechanism leading to spinal hyperexcitability and increased pain perception.

Key words: CGRP; substance $P$; nitric oxide; pain; hyperalgesia; confocal microscopy; electron microscopy; NMDA receptor; calcium signaling; spinal cord slice
The free radical gas nitric oxide (NO) has been recently identified as a neuronal messenger that performs diverse signaling functions in the nervous system. NO is an unconventional transmitter because it is not packaged in vesicles and it can cross cell membranes rapidly diffusing from the site of production in the absence of any specialized release machinery (Schuman and Madison, 1994). Within the CNS NO represents an intracellular signaling molecule with an important modulatory action on the NMDA glutamate receptor subtype (Wood, 1995). NO is also considered a good candidate as a retrograde signaling molecule in long-term potentiation (Schuman and Madison, 1994).

Nitric oxide synthase (NOS) immunocytochemistry, NOS mRNA in situ hybridization, and reduced nicotinamide adenine dinucleotide phosphate diaphorase (NADPH-d) histochemistry of fixed tissue are reliable methods to identify NO-producing neurons in the brain (for review, see Vincent, 1995). By this approach, powerful evidence has been provided that NO is syn-

Received May 29, 1998; revised Sept. 28, 1998; accepted Oct. 1, 1998.

This work was supported by the Italian Consiglio Nazionale delle Ricerche and Ministero dell'Universita e della Ricerca Scientifica e Technologica to A.M., Telethon-Italy Grant 1095 to G.C. and A.M., and the Armenise Foundation (Harvard University). P. A. was in receipt of a postdoctoral fellowship from the Cavalieri Ottolenghi Foundation for the study of Molecular, Cellular, and Biological Bases of Brain Functions and Disf unctions, Torino, Italy. We thank Dr. Tullio Pozzan for his continuous support and encouragement during the course of this work and for critical review of this manuscript.

Correspondence should be addressed to Dr. Adalberto Merighi, Dipartimento di Morfofisiologia Veterinaria, Via Nizza 52, I-10126 Torino, Italy, European Union. Copyright (C) 1998 Society for Neuroscience $\quad 0270-6474 / 98 / 1810375-14 \$ 05.00 / 0$ thesized in specific populations of spinal cord neurons (Valtschanoff et al., 1992; Dun et al., 1993; Laing et al., 1994; Morris et al., 1994; Vizzard et al., 1994a,b, 1995).

Among the neurons of adult rats shown to be NOS-positive and/or possessing NADPH-d activity at the light level, are those of laminae I-II (the substantia gelatinosa) of the dorsal horn (Valtschanoff et al., 1992). These laminae of the spinal cord are known to be involved in modulation of pain stimuli from the periphery (Willis and Coggeshall, 1991; Light, 1992; Meller and Gebhart, 1994). Small myelinated and unmyelinated primary afferent fibers that mediate nociception in the superficial dorsal horn contain and, likely, release the neurotransmitters L-glutamate and L-aspartate (Jahr and Jessel, 1985; Schouenborg and Sjölund, 1986; De Biasi and Rustioni, 1988; Maxwell et al., 1990; Merighi et al., 1991; Ueda et al., 1994; Valtschanoff et al., 1994) as well as a number of peptides. Among these, the calcitonin gene-related peptide (CGRP) and the substance P (De Biasi and Rustioni, 1988, 1991; Harmann et al., 1988; McNeill et al., 1988; Merighi et al., 1989, 1991, 1992; Ribeiro-Da-Silva et al., 1989; Jakab et al., 1990; Traub et al., 1990; De Koninck et al., 1992; Cuello et al., 1993; Ribeiro-Da-Silva, 1995) are the most abundant and better characterized.

In the superficial dorsal horn, NO synthesis linked to NMDA receptor activation has been implicated in the maintenance of hyperalgesia in several models of persistent pain (Meller and Gebhart, 1993, 1994). In many of the experimental conditions that can increase nociceptive transmission, the spinal NMDA-NO 
cascade is initiated by prolonged release of substance $\mathrm{P}$ and glutamate from primary afferents (McMahon et al., 1993; Radhakrishnan et al., 1995). In addition, previous studies have repeatedly demonstrated that the release of immunoreactive CGRP and substance $\mathrm{P}$ is increased in the dorsal horn during hyperalgesia (Oku et al., 1987a,b; Garry and Hargreaves, 1992; Meller and Gebhart, 1994). More recently, evidence has been obtained that sodium nitroprusside, used as an NO donor, evokes the release of CGRP and substance $\mathrm{P}$ from capsaicin-sensitive primary afferents, via NO-dependent and -independent mechanisms (Garry et al., 1994). Taken together, these data indicate the existence of active interactions among NO, glutamate, and peptides in pain modulation.

We studied here the light and ultrastructural morphology of NADPH-d-positive neurons in the gelatinosa and their relations with CGRP-, substance P-, and glutamate-immunoreactive nerve endings. In addition, we used an acute slice preparation of the spinal cord from young rats, fluorescent calcium indicators, and confocal microscopy to analyze the physiological properties of these neurons. We here provide a series of results on the connectivity and physiology of NO-producing neurons in the gelatinosa that represent, in our opinion, a step forward for the understanding of the complex interactions occurring among peptidergic and glutamatergic fibers in the processing of sensory information.

\section{MATERIALS AND METHODS}

Animals. Light and electron microscopic studies were performed on eight male Wistar rats (240-260 gm body weight). Slices for confocal microscopy were obtained from 12 male Wistar rats at postnatal day 8 (P8). All experiments were performed in strict accordance with the Italian and European Union regulations and have been authorized by the Italian Ministry of Health (ref. 600.8/82.20/AG1826).

Tissue preparation for light and ultrastructural morphology. Under deep pentobarbital anesthesia $(60 \mathrm{mg} / 100 \mathrm{gm})$, animals were injected intracardially with $1 \mathrm{ml}$ heparin $(5000 \mathrm{U} / \mathrm{ml})$ and perfused through the descending aorta with Sörensen buffer $0.1 \mathrm{M}, \mathrm{pH} 7.4$, containing $0.8 \%$ $\mathrm{NaCl}, 0.025 \% \mathrm{KCl}, 0.05 \% \mathrm{NaHCO}_{3}$ and saturated with a mixture of $95 \%$ $\mathrm{O}_{2}$ and $5 \% \mathrm{CO}_{2}$, followed by cold fixative solution. The latter consisted of $4 \%$ paraformaldehyde in PBS $0.1 \mathrm{M}, \mathrm{pH} 7.4$, for light microscopy, or $2 \%$ glutaraldehyde and 1\% paraformaldehyde in Sörensen buffer $0.1 \mathrm{M}$, $\mathrm{pH}$ 7.4, for electron microscopy. After perfusion, the spinal cord was removed, cut in $4-5-\mathrm{mm}$-thick blocks and post-fixed for $2-4 \mathrm{hr}$. Coronal and horizontal slices from different levels of the cord were cut on a vibratome at a thickness of 50-100 $\mu \mathrm{m}$.

Light microscopy. To reveal NADPH-d activity, sections were preincubated in PBS containing 1\% Triton X-100 for $10 \mathrm{~min}$ at room temperature and then transferred to a freshly prepared buffer-Triton solution containing $1 \mathrm{mg} / \mathrm{ml} \beta$-NADPH (Sigma, Poole, UK) and $0.2 \mathrm{mg} / \mathrm{ml}$ nitro blue tetrazolium (NBT) (Sigma) or $0.6 \mathrm{mg} / \mathrm{ml} \mathrm{2-(2'-benzothiazolyl)-5-}$ styryl-3-(4'-phthalhydrazidyl) tetrazolium chloride (Sigma) for 2-4 hr at $37^{\circ} \mathrm{C}$. The reaction was monitored under the microscope and stopped by transferring sections in PBS. Some sections, after rinsing in PBS, were immunocytochemically stained for substance P, CGRP, or the NMDAR1 receptor using the avidin-biotin-peroxidase procedure (Vector Laboratories).

Electron microscopy. Sections were preincubated in PBS containing $0.25 \%$ Triton X-100 for $10 \mathrm{~min}$ at room temperature and processed for the histochemical visualization of NADPH-d as previously described for light microscopy.

NBT-labeled sections were then post-fixed in osmium ferrocyanide for $1 \mathrm{hr}$ at $4^{\circ} \mathrm{C}$, stained with $1 \%$ uranyl acetate in maleate buffer for $1 \mathrm{hr}$ at $4^{\circ} \mathrm{C}$, dehydrated in increasing concentrations of ethanol, and flatembedded in Araldite. After observation in the light microscope and camera lucida drawings (Merighi et al., 1992), areas of interest were trimmed out and reembedded. A particular care was exercised in section trimming to ensure accurate definition of laminar boundaries. These latter were further assessed by examination of toluidine blue-stained semithin sections. Series of at least 10-20 ultrathin sections were cut to allow for a unequivocal classification of different synapses on the basis of the postsynaptic densification and type, size, and appearance of vesicles.
Sections were then collected on single slot copper grids or uncoated nickel grids (200 mesh). These latter were processed for immunostaining as previously described (Merighi and Polak, 1993). Briefly, sections were treated for $3 \mathrm{~min}$ at room temperature with a saturated aqueous solution of sodium metaperiodate (Sigma), rinsed in 1\% Triton X-100 in Trisbuffered saline (TBS) $0.5 \mathrm{M}$, pH 7.4, and then incubated for $1 \mathrm{hr}$ in $10 \%$ normal serum. Grids were then placed on drops of diluted primary antibodies (see below) and incubated overnight at $4^{\circ} \mathrm{C}$. After extensive rinsing in TBS, they were incubated in the appropriate gold conjugates (diluted 1:50), transferred into drops of $2.5 \%$ glutaraldehyde in Sörensen buffer $0.1 \mathrm{M}, \mathrm{pH} 7.4$, and finally washed in distilled water. The sections were counterstained further with uranyl acetate and lead citrate before observation with a Siemens Elmiskop 102 or a Philips CM10 electron microscope.

For quantitative analysis, three grids were randomly selected out of series cut from blocks $(n=12)$ of the lumbar spinal cord from four different animals. The boundaries of lamina II were observed at a very low magnification $(250 \times)$, and a photograph was taken at the top left corner of each square of the grid comprising the gelatinosa at the magnification of $8900 \times$.

Antibodies and controls. In this study we used primary antibodies against CGRP (polyclonal, 1:500), substance P (rat monoclonal, 1:40), and glutamate (polyclonal, 1:2000). All these antibodies have been extensively characterized in previous work, and readers are referred to published data for details on their use and specificity (Merighi et al., 1988, 1989, 1991). We also used an antibody against the NMDAR1 glutamate receptor (monoclonal, 1:250; PharMingen, San Diego, CA). Immunocytochemical controls were routinely performed as described elsewhere (Merighi and Polak, 1993).

Slice preparation for confocal microscopy. Transverse slices of the spinal cord $(300-350 \mu \mathrm{m})$ were prepared by modifying a protocol originally developed for visual cortical slices (Carmignoto and Vicini, 1992). Briefly, animals were killed by decapitation, and the body was immediately immersed in ice-cooled physiological saline (in mM: $\mathrm{NaCl}, 120$; $\mathrm{KCl}, 3.1 ; \mathrm{NaH}_{2} \mathrm{PO}_{4}, 1.25 ; \mathrm{NaHCO}_{3}, 25 ;$ dextrose, $4 ; \mathrm{MgCl}_{2}, 2 ; \mathrm{CaCl}_{2}, 1$; NaPyruvate, 2; myoinositol, 0.5; and ascorbic acid, 0.1, pH 7.4, with 5\% $\mathrm{CO}_{2}$ and $\left.95 \% \mathrm{O}_{2}\right)$. A laminectomy was performed, and the thoracic and lumbar segments of the cord were carefully dissected out and sliced with a vibratome. During the entire procedure the cord remained covered with cold physiological saline.

Slices were then incubated in physiological saline containing $20 \mu \mathrm{M}$ Indo-1 AM (Molecular Probes, Eugene, OR) and $0.02 \%$ pluronic acid at $37^{\circ} \mathrm{C}$ for $40-50 \mathrm{~min}$ under continuous mild stirring and $95 \% \mathrm{O}_{2}$ and $5 \%$ $\mathrm{CO}_{2}$ flux.

Confocal microscopy: ratio image acquisition. Recording sessions were performed at room temperature. After incubation with Indo-1 AM, slices were mounted in a chamber that was placed on the stage of a Nikon inverted microscope (Diaphot 300), equipped with a $40 \times$ water immersion objective (Nikon; NA, 1.1) connected with a real time confocal microscope (Nikon model RCM8000). The $351 \mathrm{~nm}$ band of the argon ion laser was used for excitation and the emitted light, separated into its two components ( 405 and $485 \mathrm{~nm}$ ) by a dichroic mirror, was collected by two separate photomultipliers. The ratio of intensity of the light emitted at the two wavelengths (R404/485) was displayed as a pseudocolor scale. Time series were acquired with a frame interval of 1,2 , or $3 \mathrm{sec}$, and 16 images were averaged for each frame. During recordings, slices were continuously perfused $(3 \mathrm{ml} / \mathrm{min})$ with physiological saline (in $\mathrm{mm}$ : $\mathrm{NaCl}, 120 ; \mathrm{KCl}, 3.1 ; \mathrm{NaH}_{2} \mathrm{PO}_{4}, 1.25 ; \mathrm{NaHCO}_{3}, 25$; dextrose, $5 ; \mathrm{MgCl}_{2}$, 1; and $\mathrm{CaCl}_{2}, 2, \mathrm{pH} 7.4$, with $5 \% \mathrm{CO}_{2}$ and $95 \% \mathrm{O}_{2}$ ) saturated with $95 \%$ $\mathrm{O}_{2}$ and $5 \% \mathrm{CO}_{2}$.

The response to NMDA was investigated after prolonged slice perfusion with nominally $\mathrm{Mg}^{2+}$-free solution. In a number of experiments, the stimulation with NMDA was performed in the presence of $10 \mu \mathrm{M}$ glycine.

Drugs. Substance P; $\left[\mathrm{Tyr}^{6}{ }^{6}, \mathrm{D}-\mathrm{Phe}^{7}, \mathrm{D}-\mathrm{His}^{9}\right]$-fragment $6-11$ (sendide), a highly selective and competitive antagonist of spinal substance $\mathrm{P}\left(\mathrm{NK}_{1}\right)$ receptor; L-glutamate, and NMDA were from Sigma. The NO donor 3-morpholinosydnonimine (SIN-1) was from Tocris.

\section{RESULTS}

\section{Distribution of NADPH-d-positive nerve profiles in the dorsal horn}

In both light and electron microscopy preparations the pattern of NADPH-d staining was similar, and positive neurons were mainly observed in laminae I-II of the dorsal horn (Figs. 1, 2A), lamina 


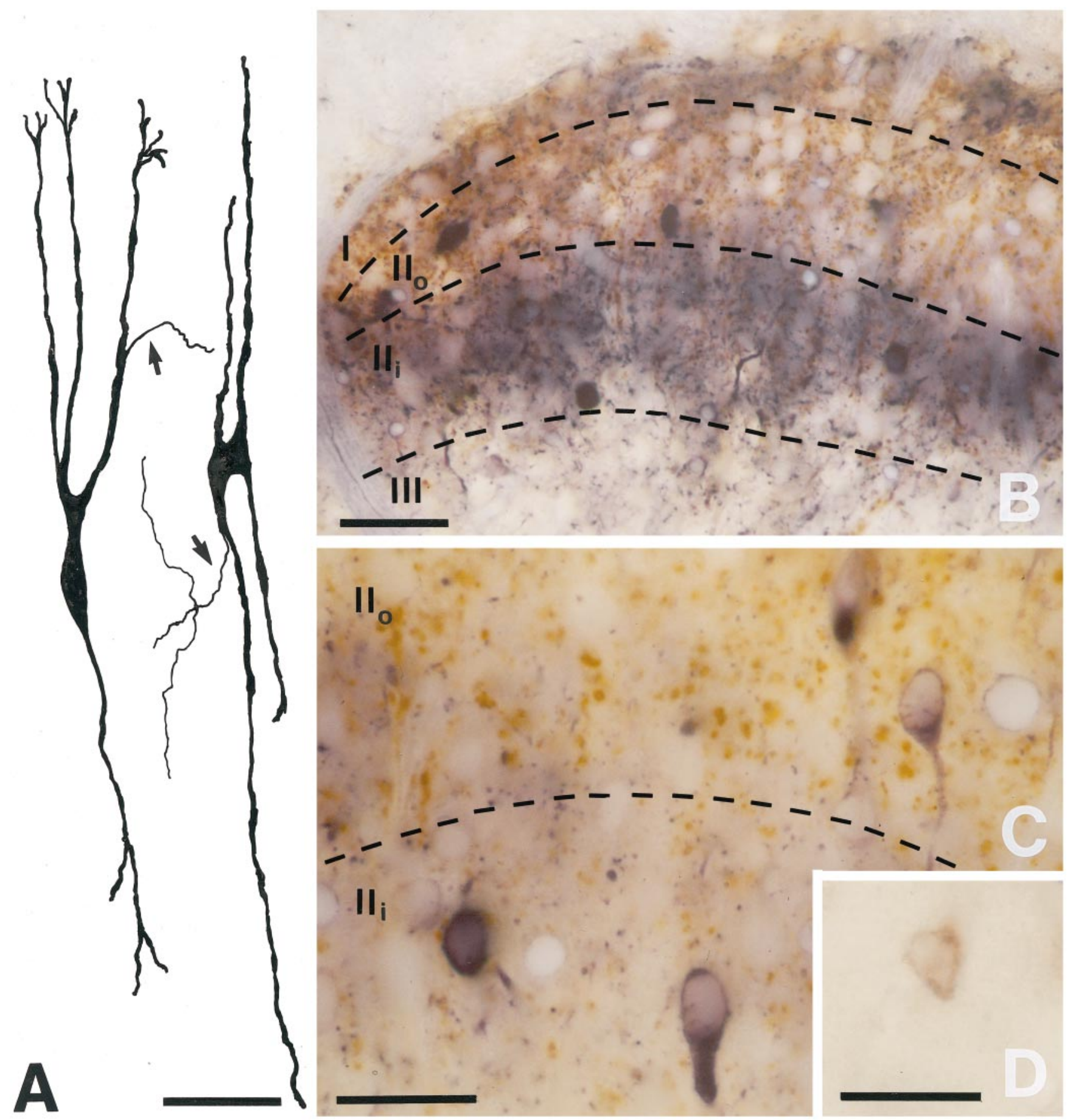

Figure 1. NADPH-d-stained neurons in the rat cervical dorsal horn. $A$, Camera lucida drawings of two NADPH-d-positive neurons from a horizontal vibratome slice cut through lamina II. The same slice was then subsequently reembedded for ultrastructural examination. Positive neurons have a fusiform shape and longitudinally oriented dendritic trees with a few long branches. The arrows indicate axon-like processes originating from proximal dendrites. $B, C$, Combined enzyme histochemistry for NADPH-d (blue) and peroxidase immunocytochemistry for substance P (brown). $B$, NADPHd-positive neuronal cell bodies and processes are particularly abundant in lamina $\mathrm{II}_{\mathrm{i}}$, whereas substance $\mathrm{P}$ immunoreactivity is mainly detected in lamina $\mathrm{II}_{\mathrm{o}}$. Lamina I shows similar densities of both labels. $C$, At higher magnification, NADPH-d positivity and substance P immunoreactivity appear to be present in different neuronal profiles. $D$, Combined enzyme histochemistry for NADPH-d (pink) and peroxidase immunocytochemistry for the NMDAR1 glutamate receptor (brownish black). A neuronal cell body in lamina $\mathrm{II}_{\mathrm{i}}$ shows colocalization of the two labels. Scale bars: $A, B, 50 \mu \mathrm{m}$; $C$, $D, 25 \mu \mathrm{m}$.

$\mathrm{X}$, and the intermediolateral cell column. Dual labeling experiments at the light microscopy level after NADPH-d staining and NMDAR1 glutamate receptor immunolabeling showed colocalization of the two labels in neurons within the superficial dorsal horn (Fig. 1D), the intermediolateral cell column, and, less frequently, lamina $X$.

At the ultrastructural level, NADPH-d positivity was detected in a number of small- to medium-sized neuronal cell bodies and 


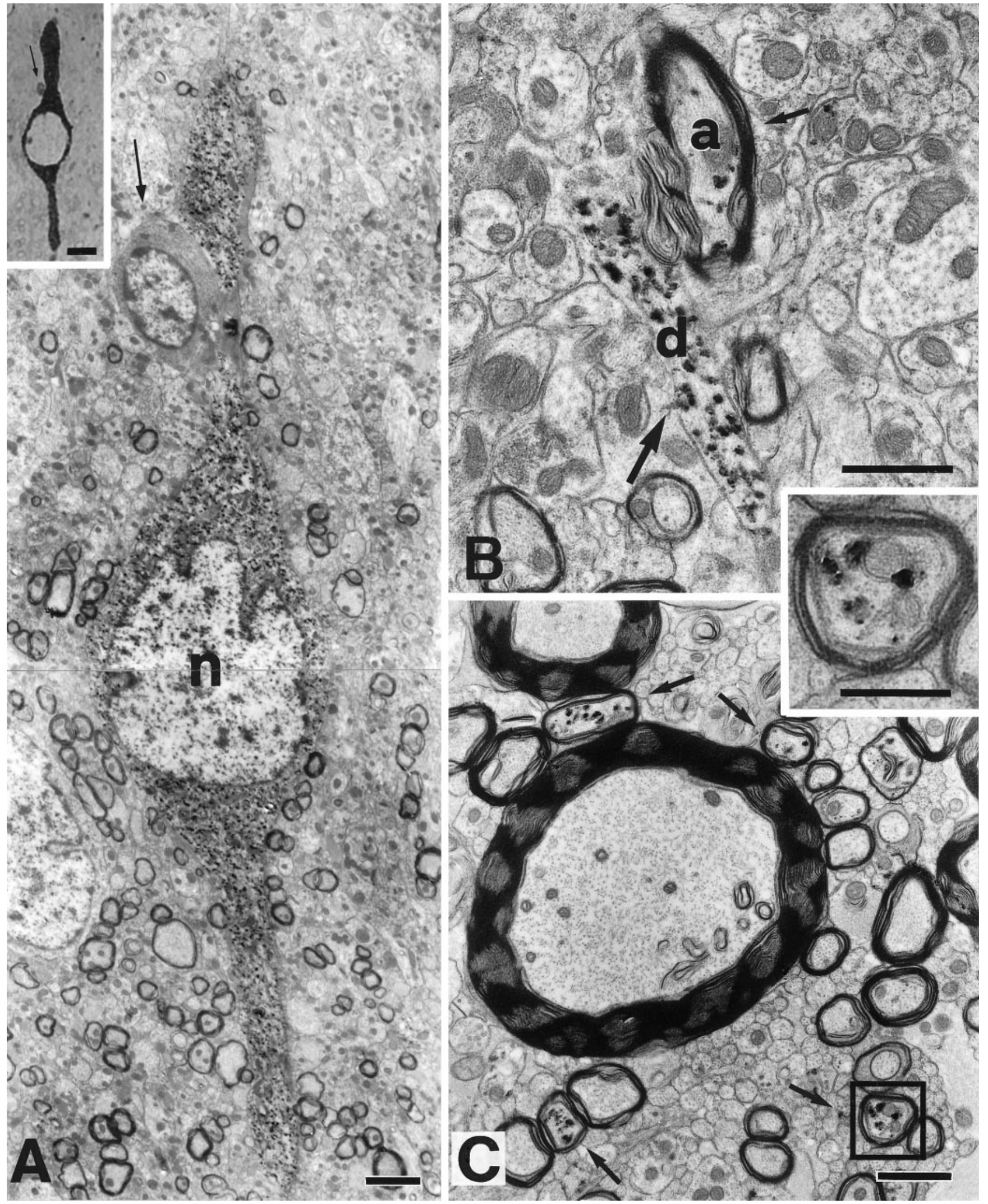

Figure 2. Ultrastructural visualization of NADPH-d positivity in the dorsal horn $(A, B)$ and Lissauer's tract $(C)$ at the lumbar level of the rat spinal cord. The NBT-positive reaction appears in the form of coarse electrondense deposits that fill almost completely the neuronal cell body and processes without any clear association with specific cell organelles. The lamina II neuron in $A$ has a typical bipolar shape, which is clearly appreciated in the corresponding unstained semithin section (insert) and a characteristically indented nucleus. The arrows point to a small nucleus used as an identifying landmark. Note in $B$ and $C$ the presence of a number of small myelinated axons containing NBT deposits within their axoplasm (arrows and insert). A positive dendrite is also indicated (long arrow) in B. $a$, Axon; $d$, dendrite; $n$, nucleus. Scale bars: $A-C, 1 \mu \mathrm{m}$; inserts, $0.25 \mu \mathrm{m}$. 
processes in the dorsal horn from all segments of the spinal cord (Figs. 2, 3). A positive reaction was also detected in the Lissauer's tract (Fig. 2C) and at the level of the small capillary endothelium. Staining was never observed in glial cells.

Positive cell bodies in the spinal gray matter were small $(\sim 6-10$ $\mu \mathrm{m}$ ), ovoid- to fusiform-shaped, and mainly concentrated in laminae I-II (Fig. 1B). In laminae III-IV, positive cell bodies were scarce, had a larger size, and a pyramidal shape. Our correlative light and electron analysis was focused on lamina II, the substantia gelatinosa. Labeled cells in the substantia gelatinosa had their dendritic trees showing a bipolar shape and oriented along a rostrocaudal axis (Figs. $1 A, 2 A$ ). Positive cells in other laminae of the dorsal horn were by far less abundant, and, thus, it was more difficult to trace their dendritic arbors with the electron microscope. At the ultrastructural level, NADPH-d-positive dendrites were observed in all laminae of the dorsal horn but were concentrated in the inner part of lamina II (lamina II $_{\mathrm{i}}$ ) (Fig. 3C). Labeled dendrites were of varying sizes and contained a variable number of mitochondria and tubules. They were often observed in close apposition with the small bundles of fine unmyelinated axons that were characteristically present in the neuropil of the substantia gelatinosa, but only occasionally were seen in glomerular configuration (Figs. 4C, 5A,B). Frequently, positive dendrites received asymmetric synapses from axons of very small caliber (Fig. $3 B$ ) and from unlabeled dendrites of varying size (Fig. 3C). NADPH-d positive axons were concentrated in laminae I-II and the Lissauer's tract. They were usually of small size and myelinated (Fig. 2B,C).

In laminae III-V, profiles filled with the NBT formazan were usually dendrites of varying size, scattered throughout the general neuropil.

\section{Relationship of NADPH-d-positive profiles and peptide- or glutamate-immunoreactive axons and terminals}

At the light level, CGRP-substance $\mathrm{P}$ immunolabeling and NADPH-d staining showed different densities in laminae I and II (Fig. $1 B$ ). In lamina I both signals were present at similar intensities, whereas peptide staining was denser in lamina $\mathrm{II}_{\mathrm{o}}$, and NBT deposits were more concentrated in lamina $\mathrm{II}_{\mathrm{i}}$. At higher magnifications (Fig. 1C) it clearly appeared that the profiles labeled by the enzymatic and immunocytochemical reactions for CGRP-substance P were spatially segregated. At the ultrastructural level, CGRP-substance P immunostaining was mainly detected in axonal varicosities of laminae $\mathrm{I}_{-} \mathrm{II}_{\mathrm{o}}$, which sometimes formed the central boutons $\left(\mathrm{C}_{1}\right)$ of type I synaptic glomeruli. At the cellular level immunoreactivity was restricted to large granular vesicles ( $\mathrm{LGVs}$ ) within immunoreactive terminals.

When double-labeled preparations were examined with the electron microscope, the floccular NBT reaction was clearly distinguishable from the gold particles indicative of CGRPsubstance P immunolabeling (Figs. 4C, 5). Quantitative analysis of $>500$ positive profiles within laminae I-II showed that NADPH-d positivity and peptide immunoreactivities were present in different types of processes irregularly scattered in the neuropil. As to their connectivity, the following configurations were observed, and their relative percentages are given in parentheses: (1) no direct apposition of NADPH-d-positive dendrites and peptide-immunoreactive terminals (68\%) (Figs. $4 A, B, 5 B)$; (2) direct apposition with no synaptic specializations (27\%); (3) axodendritic contacts between peptide-immunoreactive terminals and NADPH-d-positive dendrites (3\%); and (4) peptide- immunoreactive terminals were seen to make an axodendritic synapse onto an unlabeled dendrite, which, in turn, was contacted by a NADPH-d-positive dendrite $(2 \%)$. Finally, when direct synaptic interactions between NADPH-d and peptide-containing profiles were observed, they only exceptionally $(0.2 \%)$ occurred at the level of type I glomeruli (Fig. 4C) and never took place at the level of those of the type II. This was further confirmed by serially sectioning a square of $\sim 1 \mathrm{~mm}^{2}$ cut from a horizontal vibratome slice of $100 \mu \mathrm{m}$ thickness through the substantia gelatinosa in which NADPH-d-positive neurons were drawn with the camera lucida (Fig. $1 A$ ), and their connectivity was subsequently examined with the electron microscope. We never observed colocalization of NADPH-d and peptide labeling in any of our preparations.

Glutamate-positive terminals often formed the core of type I and II glomeruli. In NADPH-d and glutamate double staining, NBT-labeled peripheral dendrites were observed in some type II glomeruli showing a central ending $\left(\mathrm{C}_{2}\right)$ immunolabeled with the anti-glutamate antiserum. (Fig. 5A,B). At times, the two types of profiles appeared to be apposed in nonglomerular configurations with or without synaptic specializations. Most frequently, however, glutamate-positive axons and NADPH-d-labeled dendrites were spatially segregated.

\section{Confocal microscopy}

We first investigated the responsiveness of substantia gelatinosa neurons to NMDA and substance P. Because glycine is endogenously present in the slice preparation in the initial series of experiments, the stimulation with NMDA was performed in the absence of exogenously applied glycine. As illustrated in the series of pseudocolor images of Figure $6 A$, the stimulation with NMDA $(100 \mu \mathrm{M})$ in a nominally $\mathrm{Mg}^{2+}$-free solution induced a clear $\left[\mathrm{Ca}^{2+}\right]_{\mathrm{i}}$ increase in a neuron localized at $\sim 100 \mu \mathrm{m}$ from the dorsal hedge of the dorsal horn, whereas no $\left[\mathrm{Ca}^{2+}\right]_{\mathrm{i}}$ change was observed after stimulation with substance $\mathrm{P}(10 \mu \mathrm{M})$. As reported in Figure $6 B$, the response was typically characterized by slow kinetics of the $\left[\mathrm{Ca}^{2+}\right]_{\mathrm{i}}$ rise followed by a long-lasting plateau. In contrast, substance $\mathrm{P}$ induced a transient $\left[\mathrm{Ca}^{2+}\right]_{i}$ rise in the NMDA-unresponsive neuron (mean \pm SEM; time to peak, $5.5 \pm$ 0.59 ; decay, $23.3 \pm 2.04 ; n=18)$ and no $\left[\mathrm{Ca}^{2+}\right]_{\mathrm{i}}$ change in the NMDA-responsive neuron. The $\left[\mathrm{Ca}^{2+}\right]_{i}$ increase of substance P-responsive neurons often displayed an oscillatory pattern. Approximately $8.7 \%$ of the cells (11 of $126 ; 17$ experiments) responded exclusively to NMDA stimulation, whereas $69.8 \%$ (88 of 126) responded exclusively to substance P. A number of cells ( $n=$ $24 ; 19 \%$ ) did not respond to either agent; eight of these cells were classified as astrocytes (Pasti et al., 1997). Neurons formed, therefore, two main distinct populations. It is noteworthy that substance P-responsive neurons were, as a general trend, close to the surface of the dorsal horn, whereas the NMDA-responsive neurons were deeper. Some of these neurons showed a bipolar-like shape reminiscent of that of the NADPH-d-positive neurons at corresponding locations (Fig. $6 A, d, e$ ). When stimulation with NMDA was performed in the presence of $10 \mu \mathrm{M}$ glycine $(n=99$; 11 experiments), the response of the $\left[\mathrm{Ca}^{2+}\right]_{\mathrm{i}}$ increase was slightly, although not significantly, higher with respect to that observed the absence of exogenously applied glycine (mean change in R405/ $485 \pm$ SEM, $0.78 \pm 0.09$ vs $0.57 \pm 0.07 ; t$ test not significant), and the percentage of NMDA-responsive neurons was increased (16.2 vs $8.7 \%$ ). Neurons responding to both substance P and NMDA were very few ( 8 of $99,8.1 \%$ ), whereas the great majority responded exclusively to either substance P $(61$ of $99,61.7 \%)$ or 

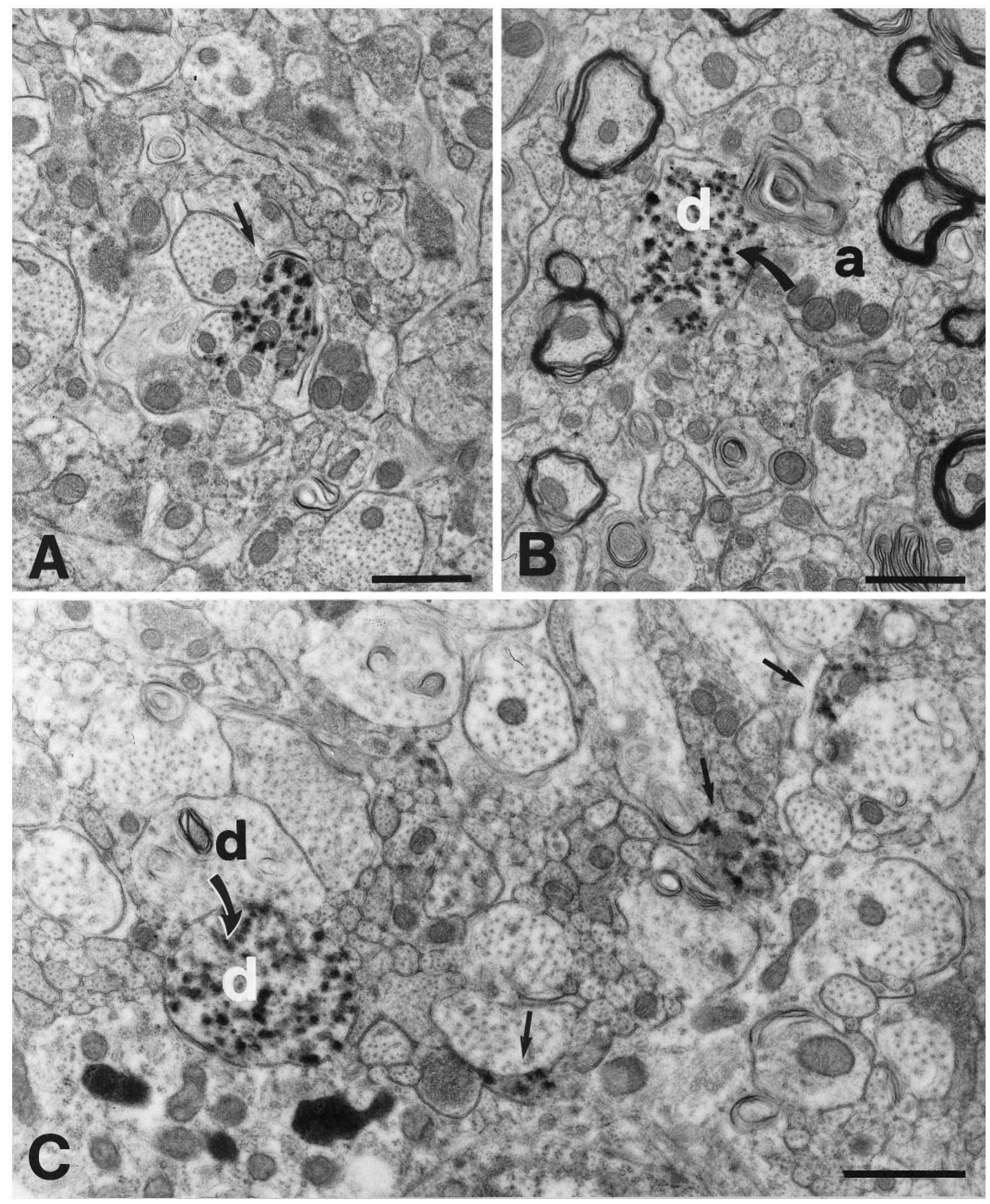

Figure 3. Distribution and connectivity of NADPH-d-positive nerve processes in the lumbar dorsal horn. $A$, An isolated labeled dendrite (arrow) in lamina I. B, A NADPH-d-positive dendrite (white $d$ ) in lamina III receives a synaptic contact (curved arrow) from an unlabeled axon $(a)$ ). $C$, NADPH-d-positive nerve processes in lamina $\mathrm{II}_{\mathrm{i}}$. A large positive dendrite (white $d$ ) receives a synapse (curved arrow) from an adjacent unlabeled dendrite (black $d$ ). Other NADPH-d-positive profiles of smaller caliber (arrows) are part of the dense meshwork of neuronal processes that is observed in lamina $\mathrm{II}_{\mathrm{i}} \cdot a$, Axon; $d$, dendrite. Scale bars, $1 \mu \mathrm{m}$. 


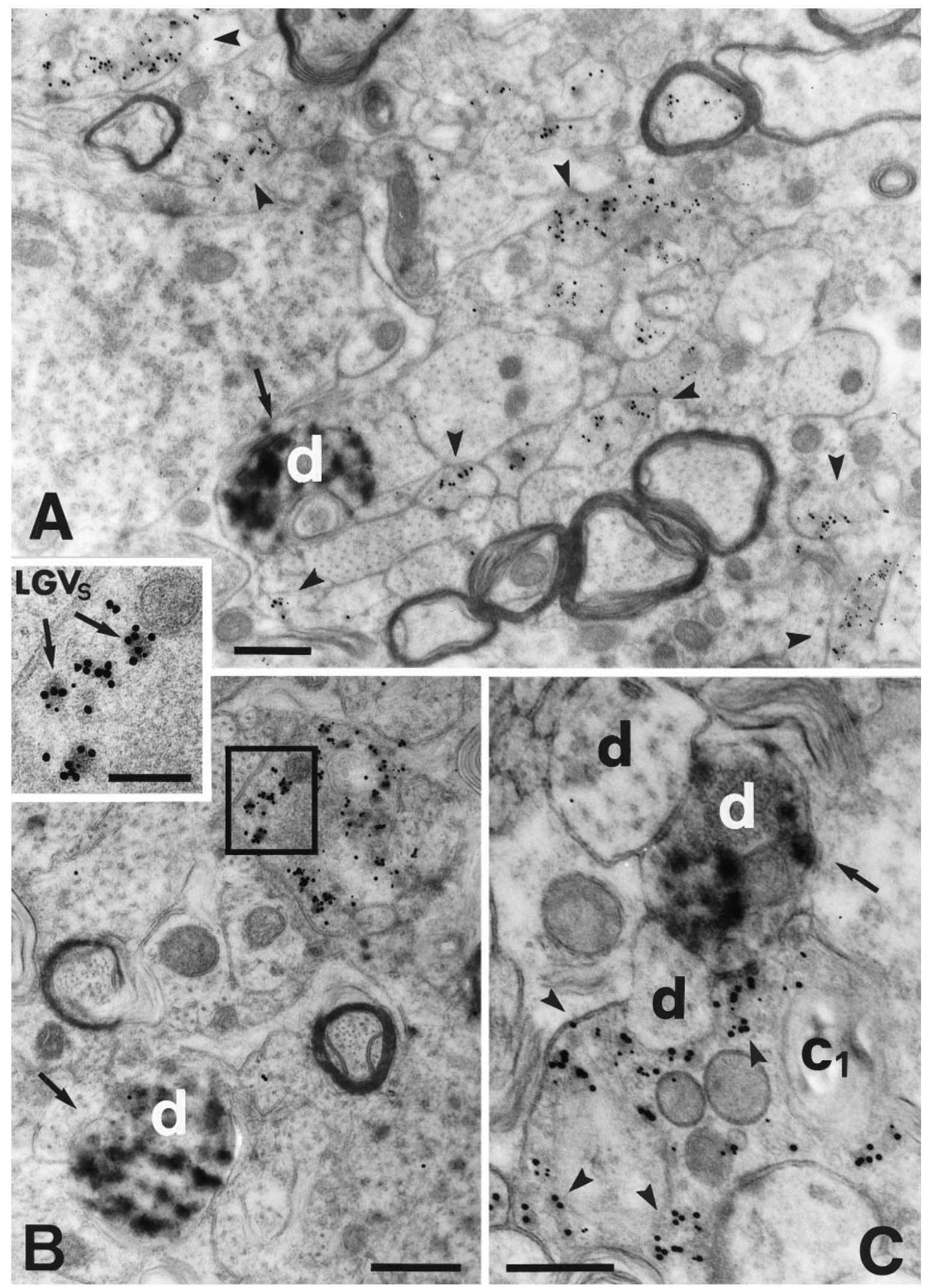

Figure 4. Combined preembedding NADPH-d histochemistry and postembedding peptide immunogold labeling in the lumbar substantia gelatinosa. $A$, A NADPH-d-positive dendrite (white $d$, arrow) in lamina $\mathrm{II}_{\mathrm{o}}$ is surrounded by a dense meshwork of CGRP-substance P double-labeled axonal profiles (arrowheads). B, A NADPH-d-positive dendrite (white d, arrow) is seen in proximity of a CGRP-substance P double-labeled axonal ending. Peptide immunoreactivity is restricted to the LGVs (insert). $C$, A NADPH-d-positive peripheral dendrite (white $d$, arrow) is part of a type I glomerulus showing a central bouton $\left(C_{1}\right)$ double-labeled for CGRP and substance P (arrowheads). $d$, Dendrite; $L G V s$, large dense-cored synaptic vesicles; CGRP, $20 \mathrm{~nm}$ gold; substance P, $10 \mathrm{~nm}$ gold. Scale bars, $0.5 \mu \mathrm{m}$. 

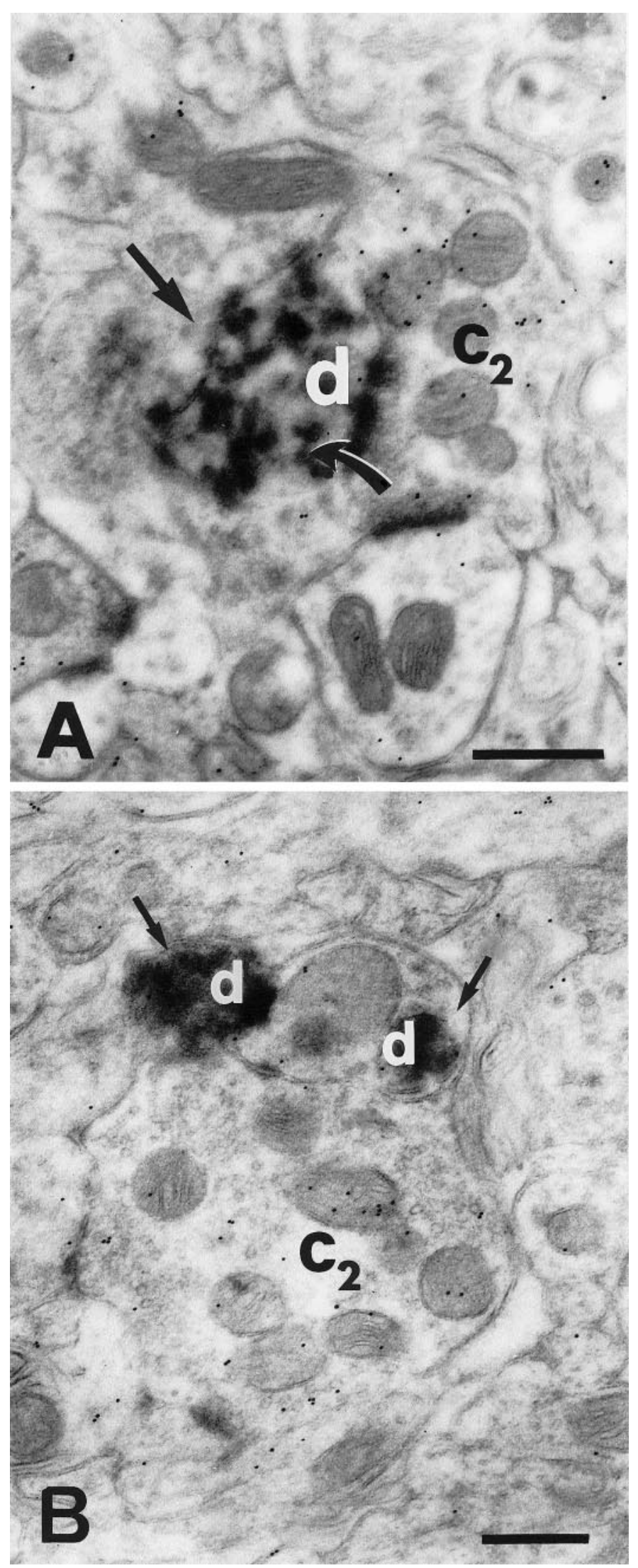

Figure 5. Combined preembedding NADPH-d histochemistry and postembedding glutamate immunogold labeling in the lumbar lamina $\mathrm{II}_{\mathrm{i}}$. $A$, A NADPH-d-positive dendrite (white $d$, arrow) is part of a type II glomerulus showing a central bouton $\left(C_{2}\right)$ containing $10 \mathrm{~nm}$ gold particles
NMDA (16 of 99, 16.2\%). In two experiments, a lower dose of substance $\mathrm{P}(1 \mu \mathrm{M})$ induced the response in 17 of $30(57 \%)$ cells, and mean $\left[\mathrm{Ca}^{2+}\right]_{\mathrm{i}}$ increase was comparable to that observed with $10 \mu \mathrm{M}$.

In a second group of experiments we analyzed the possible effect of the NO donor SIN-1 on the $\left[\mathrm{Ca}^{2+}\right]_{\mathrm{i}}$ change in different neurons. Figure 7 reports the $\left[\mathrm{Ca}^{2+}\right]_{i}$ change in one neuron localized close to the dorsal surface of the dorsal horn after successive stimulation with SIN-1 in the presence and absence of the $\mathrm{NK}_{1}$ receptor inhibitor sendide, substance $\mathrm{P}$, and NMDA. This neuron displayed a significant $\left[\mathrm{Ca}^{2+}\right]_{\mathrm{i}}$ increase on the first SIN-1 stimulation $(200 \mu \mathrm{M})$. A second stimulation with SIN-1 was then applied (time interval, $15 \mathrm{~min}$ ) together with the $\mathrm{NK}_{1}$ receptor antagonist sendide $(5 \mu \mathrm{M})$. Under these conditions, no significant variations in $\left[\mathrm{Ca}^{2+}\right]_{\mathrm{i}}$ were observed, but the response to SIN-1 was recovered after wash-out of the $\mathrm{NK}_{1}$ antagonist and an interval of $15 \mathrm{~min}$. In the same neuron, substance $\mathrm{P}(10 \mu \mathrm{M})$ induced a $\left[\mathrm{Ca}^{2+}\right]_{\mathrm{i}}$ increase whose kinetics are comparable to those observed after direct administration of the peptide in the first series of experiments. No response was observed after NMDA stimulation $(100 \mu \mathrm{M})$. In contrast, another neuron localized deeper in the dorsal horn responded to NMDA with a typical, long-lasting $\left[\mathrm{Ca}^{2+}\right]_{\mathrm{i}}$ increase (data not shown). The response to SIN-1 was inhibited completely by sendide in 5 of 28 neurons analyzed (five experiments), whereas in the other 23, the response to SIN-1 was reduced to $53 \pm 3.9 \%$ (mean change in $\mathrm{R} 405 / 485 \pm$ SEM, $0.16 \pm 0.02$ before and $0.07 \pm 0.01$ after sendide; $t$ test, $p<0.001)$. It is noteworthy that, in all substance $\mathrm{P}$-responsive neurons investigated, the response to substance $\mathrm{P}$ was blocked by sendide $(5 \mu \mathrm{M})$.

\section{DISCUSSION}

This study provides correlative morphological and functional evidence for a nonsynaptic NO-mediated release of sensory neuropeptides in the rat dorsal horn. Moreover, it shows that the main source of $\mathrm{NO}$ are the islet cells within lamina $\mathrm{II}_{\mathrm{i}}$ and that the interactions of these cells and glutamate-immunoreactive primary afferent fibers primarily occur at the level of type II synaptic glomeruli (Fig. 8). First, we will discuss our results on the nature and connectivity of NO-producing neurons after combined NADPH-d histochemistry and peptide-glutamate immunocytochemistry. We will then consider the physiological properties of these neurons in terms of their $\left[\mathrm{Ca}^{2+}\right]_{i}$ change after specific stimuli, such as activation of the $\mathrm{NMDA} / \mathrm{NK}_{1}$ receptors. Finally, on the basis of our findings, we will provide a hypothetical model to explain some of the interactions occurring among NO, peptidergic, and glutamatergic fibers in the processing of sensory information.

\section{NADPH-d positive neurons in the superficial dorsal horn}

The majority of NADPH-d positive neurons in the rat dorsal horn as described in this correlative light and electron microscopic analysis, were located in lamina II and most likely corresponded to islet cells (Gobel, 1979), as previously suggested by others after light microscopy NADPH-d stain and/or NOS immunocytochem-

indicative of glutamate immunoreactivity. Note the axodendritic contact between the two profiles (curved arrow). B, Two NADPH-d peripheral dendrites (white $d$, arrow) in a glutamate-immunoreactive type II glomerulus. $d$, Dendrite; $C_{2}$, central ending in glomerulus. Scale bars, $0.5 \mu \mathrm{m}$. 

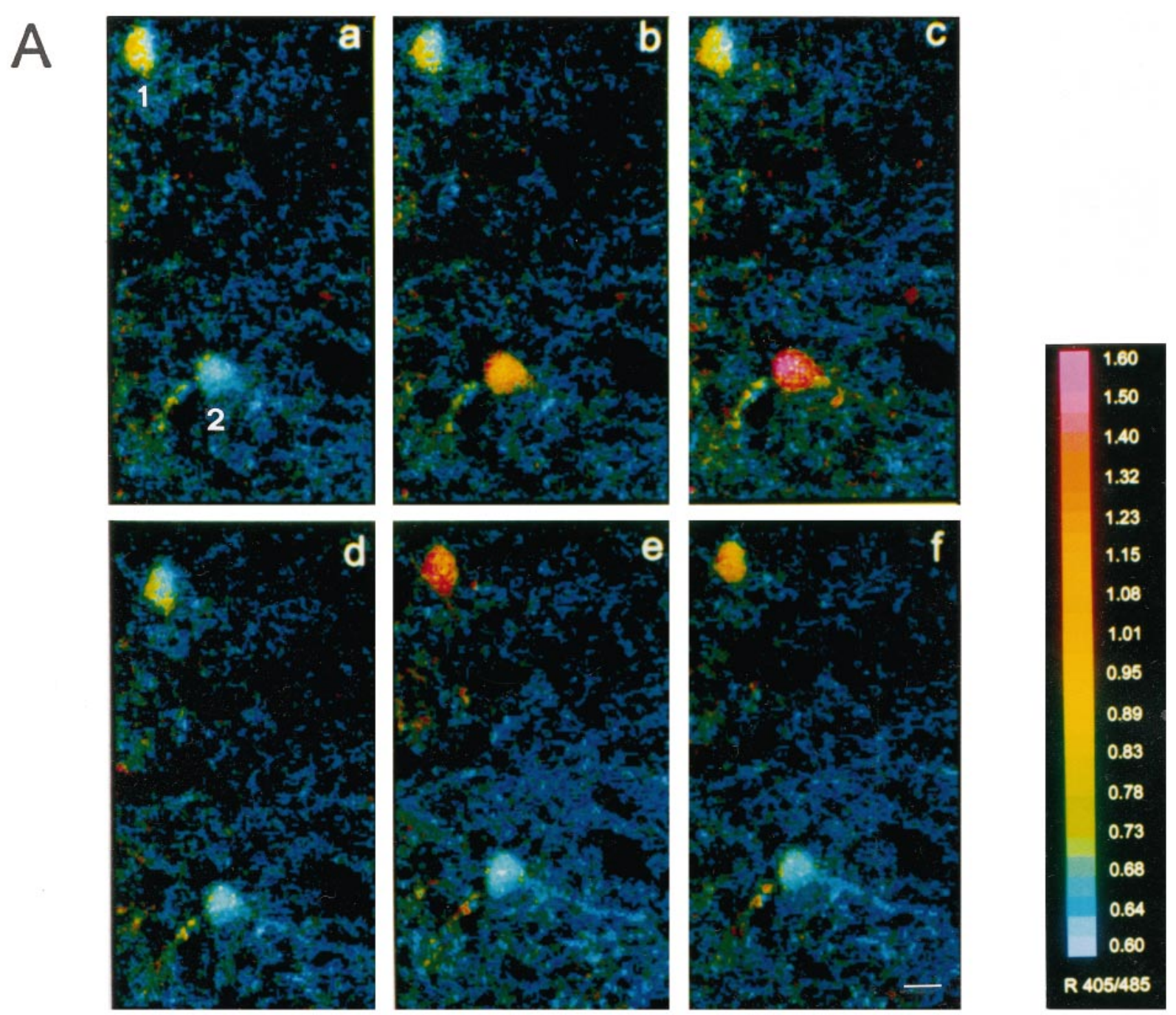

\section{cell 1}
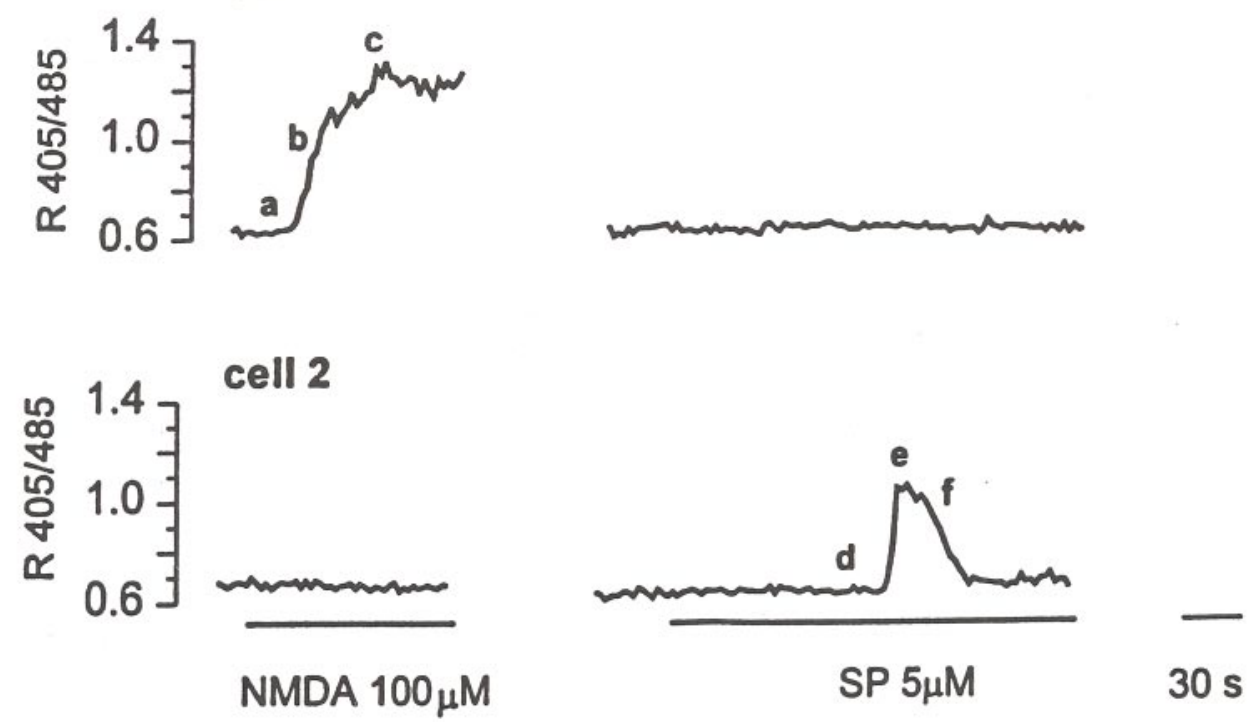

Figure 6. Different responses of substantia gelatinosa neurons to stimulation with substance $\mathrm{P}$ and NMDA. $A$, Time series of pseudocolor images of the $\left[\mathrm{Ca}^{2+}\right]_{\mathrm{i}}$ changes occurring in two Indo-1-loaded cells (1 and 2) from the dorsal horn of a young rat (P8) after subsequent perfusion of the slice with $100 \mu \mathrm{M}$ NMDA (sequence $a-c$ ) and $5 \mu \mathrm{M}$ substance $\mathrm{P}$ (sequence $d-f$ ). Images in $a-f$ correspond to the time points $a-f$ indicated in $B$. The R405/485 is displayed as a pseudocolor scale. Sampling rate, $2 \mathrm{sec}$. Scale bar, $10 \mu \mathrm{m} . B$, Kinetics of the $\left[\mathrm{Ca}^{2+}\right]_{\mathrm{i}}$ changes in cell 1 and cell 2 after NMDA and substance $\mathrm{P}$ stimulation, as expressed by the ratio between Indo-1 emission wavelength at 405 and $485 \mathrm{~nm}$. Calibration: $30 \mathrm{sec}$. 


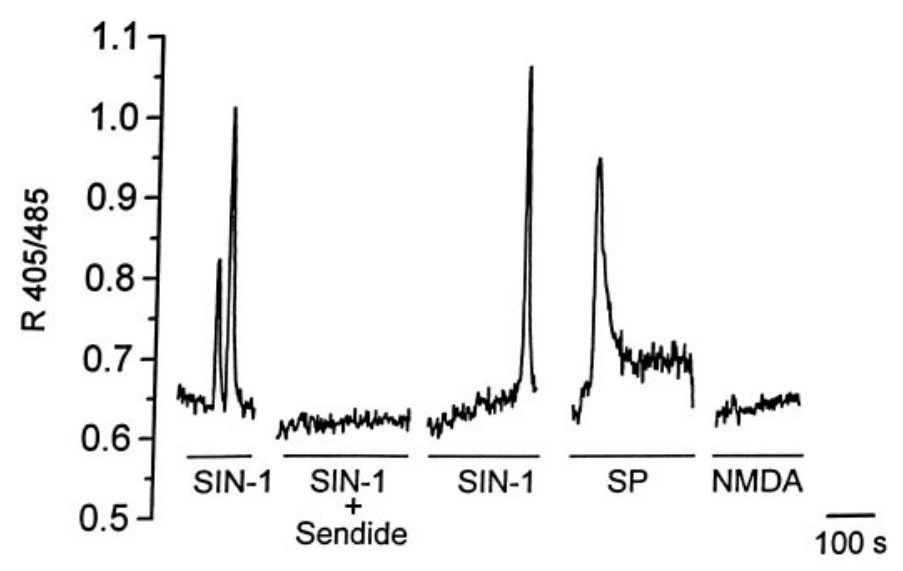

Figure 7. Kinetics of the $\left[\mathrm{Ca}^{2+}\right]_{\mathrm{i}}$ change in one typical Indo-1-loaded neuron from the $\mathrm{P} 8$ rat substantia gelatinosa, after successive stimulation with the NO donor SIN-1. The $\mathrm{NK}_{1}$ receptor antagonist sendide inhibited the response otherwise observed after SIN-1 application. The same neuron displayed a significant $\left[\mathrm{Ca}^{2+}\right]_{\mathrm{i}}$ increase on substance $\mathrm{P}$ but not NMDA stimulation. Sampling rate, $2 \mathrm{sec}$. Calibration: $100 \mathrm{sec}$.

istry (for example, see Valtshanoff et al., 1992; Vizzard et al., 1994b). Two major points arise from the present ultrastructural analysis: (1) virtually all NADPH-d-positive axons in lamina II are myelinated, and (2) there are not NADPH-d-positive terminals in this lamina, or they are extremely rare. Such an observation cannot be ascribed to technical drawbacks related to the use of the histochemical stain, considering that in the same preparations we have been able to obtain reliable terminal labeling in lamina X (Aimar et al., 1998). Therefore, our EM results imply that NADPH-d-myelinated axons likely run across the gelatinosa in the absence of an input to the lamina II neuropil from positive terminals. By using preembedding NOS immunocytochemistry Bernardi et al. (1995) have been able to show terminal staining in the dorsal horn. However, positive reaction appeared to be mainly concentrated in lamina $\mathrm{II}_{\mathrm{i}}$ and dorsal lamina III, and authors have not commented about the quantitative relevance of this finding. The major contribution to axonal NADPH-d staining in the rat substantia gelatinosa appears to be related to projection fibers as well as arbors from local circuit neurons in deeper laminae (Valtshanoff et al., 1992), although a fraction of this staining, albeit very limited and restricted to certain segments of the cord, was reported to originate from NO-containing primary afferents (Aimi et al., 1991). In keeping, it was not possible to detect NADPH-d staining (this study) or NOS immunoreactivity (Bernardi et al., 1995) in primary afferent endings.

Finally, although our light and EM NADPH-d staining suggests that positive neurons in the gelatinosa are mainly islet cells, the lack of staining in unmyelinated axons and/or terminals is puzzling. Indeed, numerous Golgi studies reported that islet cells have local axon arbors (Gobel, 1975; Bennet et al., 1980; Willis and Coggeshall, 1991), which at EM level resulted to be unmyelinated (Falls and Gobel, 1979; Gobel et al., 1980). Nonetheless, the existence of some islet cells sending their axons outside lamina II cannot be completely ruled out (Todd and Lewis, 1986; Spike and Todd, 1992). Under this context, the possibility that (some) NADPH-d-positive (islet) cells send their axons outside the substantia gelatinosa would be in agreement with previous studies on Golgi-stained preparations (Abdel-Maguid and Bowsher, 1984; Spike and Todd, 1992).
NADPH-d positive neurons and primary afferent fibers in laminae I-II

Three main types of primary afferent terminal configurations have been described in the superficial dorsal horn. These are the central terminals of type I and type II glomeruli, usually referred to as $\mathrm{C}_{1}$ and $\mathrm{C}_{2}$, respectively, which have different and peculiar ultrastructural and neurochemical features, and a third nonglomerular type particularly enriched of peptide-containing LGVs (Knyihar-Csillik et al., 1982; Coimbra et al., 1984; Valtschanoff et al., 1994). Our results demonstrate the lack of coexistence between NADPH-d staining and peptide immunoreactivity in the superficial dorsal horn. Nonetheless, NADPH-d-positive dendrites were commonly seen close to immunoreactive primary afferent axonal varicosities and terminals of the nonglomerular type containing significant numbers of CGRP-substance P-immunolabeled LGVs, but synapses between the two types of profiles were exceptional. In addition, NADPH-d-positive dendrites were, at times, detected at the periphery of type II glomeruli with glutamate-immunoreactive central boutons $\left(\mathrm{C}_{2}\right)$, and, less frequently, were contacted by glutamate-positive axons at simple axodendritic synapses.

\section{Functional properties of neurons in the superficial dorsal horn}

Our confocal experiments clearly demonstrate that neurons with functional NMDA receptors (1) are preferentially located in lamina $\mathrm{II}_{\mathrm{i}}$, as previously suggested by in situ hybridization studies on the distribution of spinal cord neurons expressing functional NMDAR1-NMDAR2D receptor complex (Tölle et al., 1993, 1995), and (2) show a laminar distribution and have morphological features resembling those of NADPH-d-positive neurons, in keeping with the results of our double-labeling experiments showing the colocalization of NADPH-d labeling and NMDAR1 immunoreactivity, and the observation that NOS-containing neurons in the spinal trigeminal nucleus of the rat express NMDA receptor mRNA (Dohrn and Beitz, 1994). As to the identification of a neuronal type or types in the confocal microscope, it seems of relevance to note that loading of Indo-1 AM into dendrites was, in general, insufficient for a clear visualization of the dendritic arbor, and, thus, it did not permit an unambiguous cell classification on the basis of pure morphological criteria. However, in a number of neurons the dendritic arborization could be followed at various focus planes by increasing the laser power. It is noteworthy that some, although not all, of these neurons were morphologically similar to NADPH-d-positive neurons (islet cells). It seems of relevance to point out that the maturation of the islet cell dendrites occurs after birth (Falls and Gobel, 1979), and the characteristic bipolar shape of their dendritic arbors is first seen at P5, and fully completed after P20 in the rat (Bicknell and Beal, 1984). Because our confocal microscope experiments were performed on slices from P8 rats, the morphological identification of islet cells on the basis of their dendritic arborization could not be (always) considered a reliable approach.

Perhaps the most intriguing result of our study is that the great majority of neurons in laminae I-II responded exclusively to either substance P or NMDA, and very few appeared to respond to both agents. This result may have a series of implications for the understanding of the mechanism by which substance P contributes to the modulation of the synaptic information transfer in the dorsal horn. It is known, for example, that substance P can potentiate the action of glutamate on the NMDA receptor in a large number of substantia gelatinosa neurons (Randic et al., 


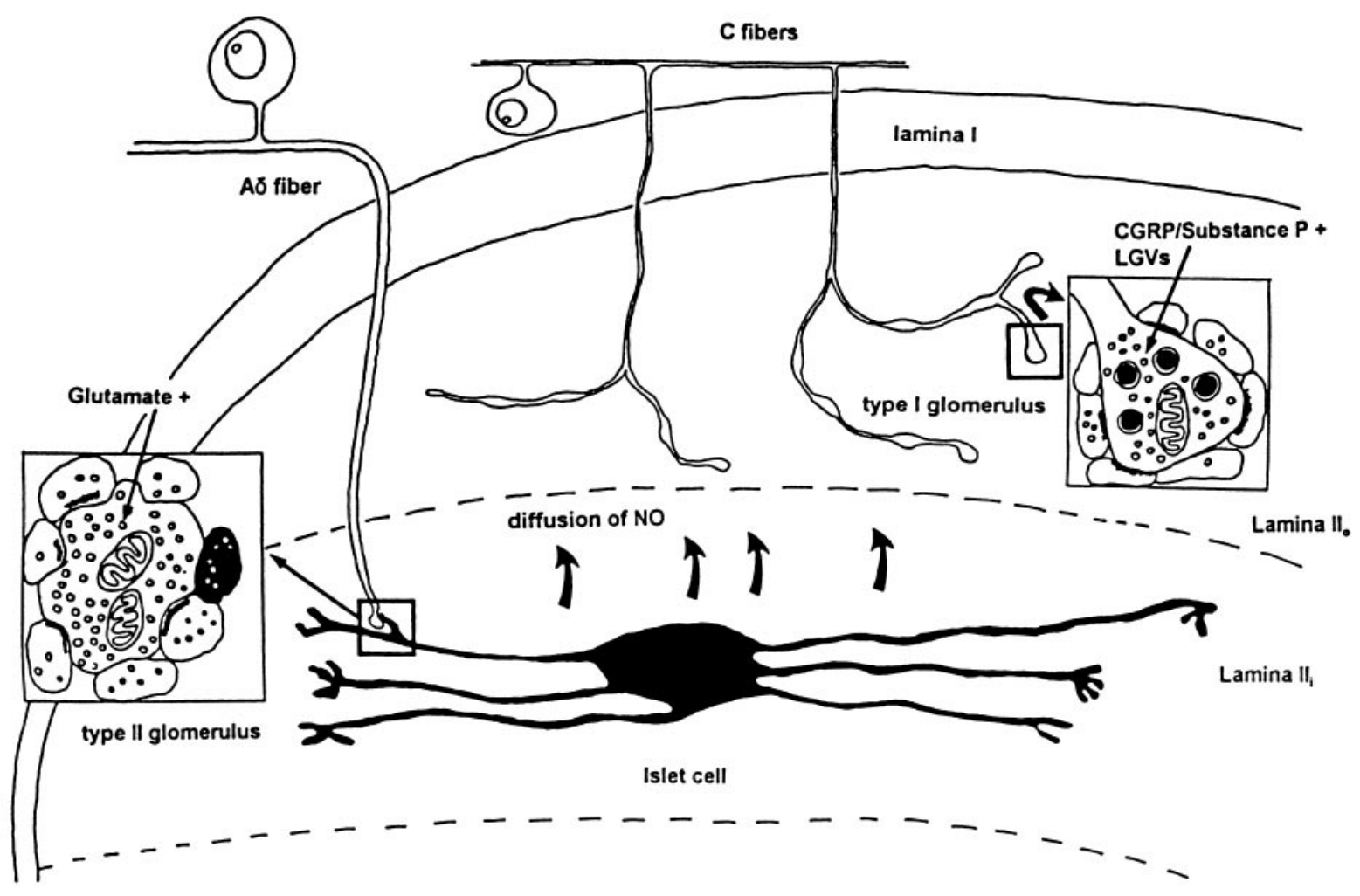

Figure 8. Hypothetical mechanism of action of NO on peptide-containing primary afferent C fibers. Stimulation of A $\delta$ afferents evokes a release of glutamate from $\mathrm{C}_{2}$ central endings in type II glomeruli within lamina $\mathrm{II}_{\mathrm{i}}$. In hyperalgesic conditions, such a stimulation would be effective in activating the NMDA-NO cascade in the peripheral dendrites of glomeruli, which originate from NADPH-d-positive islet cells. NO released from the dendritic tree of islet cells diff uses throughout lamina $\mathrm{II}_{\mathrm{o}}$ and enhances the release of substance P (and CGRP) from $\mathrm{C}$ fiber varicosities and terminals, which are enriched of peptide-containing LGVs. The simultaneous and prolonged release of sensory neuropeptides throughout the substantia gelatinosa represents one of the mechanisms of central sensitization.

1990). Accordingly, it is proposed that substance P may directly modulate the NMDA receptor, assuming that $\mathrm{NK}_{1}$ and NMDARs are expressed in the same neuronal population (for example, see Levine et al., 1993). In contrast, our results support the view that substance $\mathrm{P}$ may modulate the NMDA receptor response indirectly, for example, acting on neurons from deeper laminae whose dendrites are postsynaptic targets of $\mathrm{C}$ fiber terminals in laminae I-II. An alternative, plausible hypothesis is that the ability of substance $P$ to induce repetitive $\left[\mathrm{Ca}^{2+}\right]_{i}$ transients is independent on its effects on the NMDA receptor. It is noteworthy that substance $\mathrm{P}$ is known to slowly depolarize dorsal horn neurons because of its blocking action on potassium channels (Takano et al., 1995). The $\left[\mathrm{Ca}^{2+}\right]_{i}$ increase resulting from this action of substance $\mathrm{P}$ could probably be rather slow occurring in several minutes and might not have been detected under our experimental conditions. This type of effect might be important for the modulatory action of substance $\mathrm{P}$ on the NMDA receptor.

Our work also shows the existence of a relatively large population of neurons $\left(77.1 \%\right.$ of cells analyzed) in laminae ${\mathrm{I}-\mathrm{II}_{\mathrm{o}}}_{\text {which }}$ respond to substance $\mathrm{P}$ stimulation with a significant increase in $\left[\mathrm{Ca}^{2+}\right]_{\mathrm{i}}$. This response is mediated by $\mathrm{NK}_{1}$ receptors, because the $\mathrm{NK}_{1}$ receptor antagonist sendide (Sakurada et al., 1993) blocked substance P-mediated $\left[\mathrm{Ca}^{2+}\right]_{\mathrm{i}}$ increase. Such an observation is in accordance with observations on acutely dissociated young dorsal horn neurons (Rusin et al., 1993) and the reported immunocytochemical distribution of the $\mathrm{NK}_{1}$ receptor in the dorsal horn (Nakaya et al., 1994; Littlewood et al., 1995), but partly contradictory with the data suggesting that substance $\mathrm{P}$ does not have a functional role on lamina II neurons (Bleazard et al., 1994) and is not involved in the generation of slow excitatory postsynaptic currents in vitro from the gelatinosa neurons (Yajiri et al., 1997).

In addition, our results do not completely match with the data obtained by Rusin et al. (1993) who found $47 \%$ ( 8 of 17 cells) of the dorsal horn neurons responsive to both substance $\mathrm{P}$ and NMDA. It seems reasonable that the different type of preparation used by us (intact slices) and the above authors (dissociated cells) accounts for such a discrepancy. Because substance P- and NMDA-responsive neurons have a different laminar (and even sublaminar) distribution (see above), and the adult rat lamina II is $<100-\mu \mathrm{m}$-thick (Ribeiro da Silva and Coimbra, 1982), it cannot be excluded that sampling in cell isolation dramatically affects the type(s) of neurons that will be present in the final preparation. Indeed, several studies have reported only a few (if any) $\mathrm{NK}_{1}$ receptor-immunoreactive neurons in lamina II (Bleazard et al., 1994; Liu et al., 1994; Littlewood et al., 1995), which, on the other hand, is densely populated by neurons expressing at least some of the components of the NMDA receptor complex, namely the NMDAR1 subunit (Tölle et al., 1993, 1995). Although of a perhaps limited numerical consistence, neurons in the dorsal horn that are responsive to both substance $\mathrm{P}$ and NMDA might represent preferential targets for those primary afferent fibers showing colocalization of substance $\mathrm{P}$ and glutamate (De Biasi and Rustioni, 1988; Merighi et al., 1991).

The neurons in the superficial dorsal horn that display a $\left[\mathrm{Ca}^{2+}\right]_{\mathrm{i}}$ increase after stimulation with substance $\mathrm{P}$ display a $\left[\mathrm{Ca}^{2+}\right]_{\mathrm{i}}$ increase also after slice perfusion with the NO donor 
SIN-1. The finding that the effect of SIN-1 is significantly inhibited by the $\mathrm{NK}_{1}$ antagonist sendide together with the similar kinetics of the $\left[\mathrm{Ca}^{2+}\right]_{i}$ change observed after substance $\mathrm{P}$ and SIN-1 provides compelling evidence that NO is capable to evoke the release in vitro of substance $\mathrm{P}$ from endogenous spinal sources (Garry et al., 1994). The inhibition was complete in 5 of 28 neurons and significantly reduced in the remaining 23 . These data suggest that other agents besides substance $\mathrm{P}$, such as the peptide CGRP, are probably released after SIN-1 stimulation and can, thus, be involved in the $\left[\mathrm{Ca}^{2+}\right]_{\mathrm{i}}$ change observed.

\section{NO-mediated release of sensory neuropeptides in the dorsal horn}

Numerous reports have shown that CGRP, substance P, glutamate, and NO are all involved in nociceptive processing and hyperalgesia in the dorsal horn (McMahon et al., 1993; Meller and Gebhart, 1993, 1994; Morris et al., 1994; Traub et al., 1994a,b; Wiertelak et al., 1994; Honoré et al., 1995; Minami et al., 1995; Vizzard et al., 1995; Aley et al., 1998). Recent findings demonstrate that sodium nitroprusside, an NO donor, evokes the release of CGRP and substance P from dorsal horn slices (Garry et al., 1994). It was also shown that NO contributes to persistent nociception and hyperalgesia induced by glutamate and substance $\mathrm{P}$ in the rat formalin pain model (Coderre and Yashpal, 1994) and that the NO inhibitor $\mathrm{N}^{\omega}$-nitro-L-arginine methyl ester (LNAME) blocks the thermal hyperalgesia induced by endogenous and exogenous substance P (Radhakrishnan et al., 1995). Release of NO is triggered by the NMDA glutamate receptor, which raises $\left[\mathrm{Ca}^{2+}\right]_{\mathrm{i}}$ and activates NOS (Schuman and Madison, 1994). In the spinal cord, NMDA-NO cascade is activated in parallel with prolonged release of substance $\mathrm{P}$ and glutamate from primary afferent endings (McMahon et al., 1993).

Our findings provide a series of new information on the interactions among NO-producing neurons and peptidergic and glutamatergic processes. On the basis of our observations we advance the following hypothesis (Fig. 8). Glutamate released at central endings $\left(\mathrm{C}_{2}\right)$ of type II glomeruli induces a $\left[\mathrm{Ca}^{2+}\right]_{\mathrm{i}}$ increase in NADPH-d-positive islet cells after activation of the NMDA receptor (some of these cells might correspond to wide dynamic range neurons, which, in certain hyperalgesic conditions, exhibit enhanced spontaneous firing; Menétrey and Besson, 1988). The NMDA-mediated $\left[\mathrm{Ca}^{2+}\right]_{i}$ rise results in the activation of NOS with the consequent release of NO. Newly generated NO could then evoke the release of substance P (and CGRP) from primary afferent endings, as demonstrated by the substance P-mediated $\left[\mathrm{Ca}^{2+}\right]_{\mathrm{i}}$ increase we observed after SIN-1 stimulation.

Type I glomeruli, which contain a $\mathrm{C}_{1}$ central ending that originates from thin unmyelinated $\mathrm{C}$ fibers (Ribeiro-Da-Silva and Coimbra, 1982; Ribeiro-Da-Silva, 1994), only exceptionally showed NADPH-d-positive dendrites. This indicates that interactions of NO-producing neurons and primary afferent fibers preferentially occur at the level of $A \delta$ fibers that form the $\mathrm{C}_{2}$ central terminals of type II glomeruli (Ribeiro-Da-Silva and Coimbra, 1982; Ribeiro-Da-Silva, 1994). This is in agreement with the recent reported finding that $\mathrm{C}_{2}$ terminals, but not the two other types of primary afferent terminals $\left(\mathrm{C}_{1}\right.$ and nonglomerular endings) that can be detected in the substantia gelatinosa, are contacted by NOS-immunoreactive dendrites (Bernardi et al., 1995).

The interactions between primary afferent fibers and NOproducing neurons primarily occur in lamina $\mathrm{II}_{\mathrm{i}}$, which is not the main site of noxious input to the gelatinosa (Willis and Cogge- shall, 1991; Light, 1992). As a possible explanation, it was suggested that $\mathrm{A} \delta$ fibers could make axodendritic contacts in lamina $\mathrm{II}_{\mathrm{o}}$ before contacting NO-producing neurons at type II glomeruli in lamina $\mathrm{II}_{\mathrm{i}}$ (Bernardi et al., 1995). However, in our preparations we were unable to observe any contact between peptideglutamate-containing terminals of presumable primary afferent origin and NADPH-d-positive dendrites in lamina $\mathrm{II}_{\mathrm{o}}$. Alternatively, and in keeping with the results we obtained, NO could influence $\mathrm{C}$ fibers simply by diffusion. Indeed, from its half-life and diffusion constant one can estimate NO to diffuse for $>50$ $\mu \mathrm{m}$ before decomposing (Kelm et al., 1988). The notion that NO is a diffusible gas messenger and has important modulatory role in neuronal function (Schuman and Madison, 1994) raises the problem of how signaling specificity can be achieved. Two recent reports indicate that specificity of action can be accomplished by requiring that messenger production coincides with synaptic activity (Peunova and Enikolopov, 1993; Zhuo et al., 1993). The high density of NADPH-d-positive dendrites in the gelatinosa, as demonstrated by our ultrastructural analysis, would allow for simultaneous release of NO and sensory neuropeptides throughout lamina $\mathrm{II}_{\mathrm{o}}$. This is consistent with the rapid increase of $\left[\mathrm{Ca}^{2+}\right]_{\mathrm{i}}$ that we observed in a subpopulation of neurons in lamina $\mathrm{I}_{-} \mathrm{II}_{\mathrm{o}}$ after SIN-1 administration and with the idea that during the course of hyperalgesia the entire dorsal horn might be flooded with substance $\mathrm{P}$ and nonsynaptic volume transmission might occur (Duggan et al., 1990).

\section{REFERENCES}

Abdel-Maguid TE, Bowsher D (1984) Interneurons and proprioneurons in the adult human spinal grey matter and in the general somatic and visceral afferent cranial nerve nuclei. J Anat 139:9-19.

Aimar P, Barajon I, Merighi A (1998) Ultrastructural features and synaptic connections of NADPH-diaphorase positive neurones in the rat spinal dorsal horn and central grey matter. Eur J Anat 2:27-33.

Aimi Y, Fujimura M, Vincent SR, Kimura H (1991) Localization of NADPH-diaphorase-containing neurons in sensory ganglia of the rat. J Comp Neurol 306:382-392.

Aley KO, McCarter G, Levine JD (1998) Nitric oxide signaling in pain and nociceptor sensitization in the rat. J Neurosci 18:7008-7014.

Bennett GJ, Abdelmoumene M, Hayashi H, Dubner R (1980) Physiology and morphology of substantia gelatinosa neurons intracellularly stained with horseradish peroxidase. J Comp Neurol 194:809-827.

Bernardi PS, Valtschanoff JG, Weinberg RJ, Schmidt HHHW, Rustioni A (1995) Synaptic interactions between primary afferent terminals and GABA and nitric oxide-synthesizing neurons in superficial laminae of the rat spinal cord. J Neurosci 15:1363-1371.

Bicknell HR, Beal JA (1984) Axonal and dendritic development of substantia gelatinosa neurons in the lumbosacral spinal cord of the rat. J Comp Neurol 226:508-522.

Bleazard L, Hill RG, Morris R (1994) The correlation between the distribution of the $\mathrm{NK}_{1}$ receptor and the actions of tachykinin agonists in the dorsal horn of the rat indicates that substance $\mathrm{P}$ does not have a functional role on substantia gelatinosa (lamina II) neurons. J Neurosci 14:7655-7664.

Carmignoto G, Vicini S (1992) Activity-dependent decrease in NMDA responses during development of the visual cortex. Science 258:1007-1011.

Coderre TJ, Yashpal K (1994) Intracellular messengers contributing to persistent nociception and hyperalgesia induced by L-glutamate and substance $\mathrm{P}$ in the rat formalin pain model. Eur $\mathrm{J}$ Neurosci 6:1328-1334.

Coimbra A, Ribeiro-Da-Silva A, Pignatelli D (1984) Effects of dorsal rhizotomy on the several types of primary afferent terminals in laminae I-III of the rat spinal cord. An electron microscope study. Anat Embryol 170:279-287.

Cuello AC, Ribeiro-Da-Silva A, Ma W, De Koninck Y, Henry JL (1993) Organization of substance P primary sensory neurons: ultrastructural and physiological correlates. Regul Pept 46:155-164.

De Biasi S, Rustioni A (1988) Glutamate and substance P coexist in 
primary afferent terminals in the superficial laminae of the spinal cord. Proc Natl Acad Sci USA 85:7820-7824.

De Biasi S, Rustioni A (1991) Ultrastructural immunocytochemical localization of excitatory amino acids in the somatosensory system. J Histochem Cytochem 38:1745-1754.

De Koninck Y, Ribeiro-Da-Silva A, Henry JL, Cuello AC (1992) Spinal neurons exhibiting a specific nociceptive response receive abundant substance P-containing synaptic contacts. Proc Natl Acad Sci USA 89:5073-5077.

Dohrn CS, Beitz AJ (1994) NMDA receptor messenger-RNA expression in NOS-containing neurons in the spinal trigeminal nucleus of the rat. Neurosci Lett 175:28-32.

Duggan AW, Hope PJ, Jarrott B, Schaible HG, Fleetwood-Walker SM (1990) Release, spread and persistence of immunoreactive neurokinin A in the dorsal horn of the cat following noxious cutaneous stimulation. Studies with antibody microprobes. Neuroscience 35:195-205.

Dun NJ, Dun SL, Wu SY, Förstermann U, Schmidt HHHW, Tseng LF (1993) Nitric oxide synthase immunoreactivity in the rat, mouse, cat and squirrel monkey spinal cord. Neuroscience 54:845-857.

Falls W, Gobel S (1979) Golgi and EM studies of the formation of dendritic and axonal arbors: the interneurons of the substantia gelatinosa of Rolando in newborn kittens. J Comp Neurol 172:511-528.

Garry MG, Hargreaves KM (1992) Enhanced release of immunoreactive CGRP and substance P from spinal dorsal horn slices occurs during carrageenan inflammation. Brain Res 582:139-142.

Garry MG, Richardson JD, Hargreaves KM (1994) Sodium nitroprusside evokes the release of immunoreactive calcitonin gene-related peptide and substance $\mathrm{P}$ from dorsal horn slices via nitric oxide-dependent and nitric oxide-independent mechanisms. J Neurosci 14:4329-4337.

Gobel S (1975) Golgi studies of the substantia gelatinosa neurons in the spinal trigeminal nucleus. J Comp Neurol 162:397-416.

Gobel S (1979) Neural circuitry in the substantia gelatinosa of Rolando: anatomical insights. Adv Pain Res Ther 3:175-195.

Gobel S, Falls WM, Bennett GJ, Abdelmoumene M, Hayashi H, Humprey E (1980) An EM analysis of the synaptic connections of horseradish peroxidase filled stalked cells and islet cells in the substantia gelatinosa of adult cat spinal cord. J Comp Neurol 194:781-807.

Harmann PA, Chung K, Briner RP, Westlund KN, Carlton SM (1988) Calcitonin Gene-Related Peptide (CGRP) in the human spinal cord: a light and electron microscopic analysis. J Comp Neurol 269:371-380.

Honoré P, Chapman V, Buritova J, Besson J-M (1995) Reduction of carrageenin oedema and the associated c-Fos expression in the rat lumbar spinal cord by nitric oxide synthase inhibitor. Br J Pharmacol 114:77-84.

Jahr CE, Jessel TM (1985) Synaptic transmission between dorsal root ganglion and dorsal horn neurons in culture: antagonism of monosynaptic excitatory postsynaptic potentials and glutamate excitation by kynurenate. J Neurosci 5:2281-2289.

Jakab G, Salamon I, Petrusz P, Rèthelyi M (1990) Termination patterns of calcitonin gene-related peptide-immunoreactive nerve fibers in the dorsal horn of the human spinal cord. Exp Brain Res 80:609-619.

Knyihar-Csillik E, Csillik B, Rakic P (1982) Ultrastructure of normal and degenerating glomerular terminals of dorsal root axons in the substantia gelatinosa of the Rhesus monkey. J Comp Neurol 210:357-375.

Laing I, Todd AJ, Heizmann CW, Schmidt HHHW (1994) Subpopulations of GABAergic neurons in laminae I-III of rat spinal dorsal horn defined by coexistence with classical transmitters, peptides, nitric oxide synthase or parvalbumin. Neuroscience 61:123-132.

Levine JD, Fields HL, Basbaum AI (1993) Peptides and the primary afferent nociceptor. J Neurosci 13:2273-2286.

Light AR (1992) The initial processing of pain and its descending control: spinal and trigeminal systems. New York: Karger.

Littlewood NK, Todd AJ, Spike RC, Watt C, Shehab SAS (1995) The types of neuron in spinal dorsal horn which possess neurokinin-1 receptors. Neuroscience 66:597-608.

Liu H, Brown JL, Jasmin L, Maggio JE, Vigna SR, Mantyh PW, Basbaum AI (1994) Synaptic relationship between substance P and the substance P receptor: light and electron microscopic characterization of the mismatch between neuropeptides and their receptors. Proc Natl Acad Sci USA 91:1009-1013.

Maxwell DJ, Christie WH, Short AD, Störm-Mathisen J, Ottersen OP (1990) Central boutons of glomeruli in the spinal cord of the cat are enriched with L-glutamate-like immunoreactivity. Neuroscience 36:83-104.
McMahon S, Lewin GR, Wall PD (1993) Central hyperexcitability triggered by noxious inputs. Curr Opin Neurobiol 3:602-610.

McNeill DL, Chung K, Carlton SM, Coggeshall RE (1988) Calcitonin gene-related peptide immunostained axons provide evidence for fine primary afferent fibers in the dorsal and dorsolateral funiculi of the rat spinal cord. J Comp Neurol 272:303-308.

Meller ST, Gebhart GF (1993) Nitric oxide (NO) and nociceptive processing in the spinal cord. Pain 52:127-136.

Meller ST, Gebhart GF (1994) Spinal mediators of hyperalgesia. Drugs 47:10-20.

Menétrey D, Besson JM (1988) Electrophysiological characteristics of dorsal horn cells in rats with cutaneous inflammation resulting from chronic arthritis. Pain 13:343-364.

Merighi A, Polak JM (1993) Post-embedding immunogold staining. In: Immunohistochemistry II (Cuello AC, ed), pp. 229-264. New York: Wiley.

Merighi A, Polak JM, Gibson SJ, Gulbenkian S, Valentino KL, Peirone SM (1988) Ultrastructural studies on calcitonin gene-related peptidetachykinins- and somatostatin-immunoreactive neurones in rat dorsal root ganglia: evidence for the colocalisation of different peptides in single secretory granules. Cell Tissue Res 254:101-109.

Merighi A, Polak JM, Fumagalli G, Theodosis DT (1989) Ultrastructural localisation of neuropeptides and GABA in the rat dorsal horn: a comparison of different immunogold labelling techniques. J Histochem Cytochem 37:529-540.

Merighi A, Polak JM, Theodosis DT (1991) Ultrastructural visualization of glutamate and aspartate immunoreactivities in the rat dorsal horn with special reference to the co-localization of glutamate, substance $\mathrm{P}$ and calcitonin gene-related peptide. Neuroscience 40:67-80.

Merighi A, Cruz F, Coimbra A (1992) Immunocytochemical staining of neuropeptides in terminal arborization of primary afferent fibers anterogradely labeled and identified at light and electron microscopic levels. J Neurosci Methods 42:105-113.

Minami T, Nishihara I, Ito S, Sakamoto K, Hyodo M, Hayaishi O (1995) Nitric oxide mediates allodynia induced by intrathecal administration of prostaglandin $\mathrm{E}_{2}$ or prostaglandin $\mathrm{F}_{2 \alpha}$ in conscious mice. Pain 61:285-290.

Morris R, Southam E, Gittins SR, De Vente J, Garthwaite J (1994) The NO-cGMP pathway in neonatal rat dorsal horn. Eur $\mathrm{J}$ Neurosci 6:876-879.

Nakaya Y, Kaneko T, Shigemoto R, Nakanishi S, Mizuno N (1994) Immunohistochemical localization of substance $\mathrm{P}$ receptor in the central nervous system of the adult rat. J Comp Neurol 347:249-274.

Oku R, Satoh M, Fuji N, Otaka A, Yajima H, Takagi H (1987a) Calcitonin gene-related peptide promotes mechanical nociception by potentiating release of substance $\mathrm{P}$ from spinal dorsal horn in rat. Brain Res 403:350-354.

Oku R, Satoh M, Takagi H (1987b) Release of substance P from the spinal dorsal horn is enhanced in polyarthritic rats. Neurosci Lett 74:315-319.

Pasti L, Volterra A, Pozzan T, Carmignoto G (1997) Intracellular calcium oscillations in astrocytes: a highly plastic, bidirectional form of communication between neurons and astrocytes in situ. J Neurosci 17:7817-7830.

Peunova N, Enikolopov G (1993) Amplification of calcium-induced gene transcription by nitric oxide in neuronal cells. Nature 364:450-453.

Radhakrishnan V, Yashpal K, Hui-Chan CWY, Henry JL (1995) Implication of a nitric oxide synthase mechanism in the action of substance P: L-NAME blocks thermal hyperalgesia induced by endogenous and exogenous substance $P$ in the rat. Eur J Neurosci 7:1920-1925.

Randic M, Hecimovic H, Ryu PD (1990) Substance P modulates glutamate-induced currents in acutely isolated rat spinal dorsal horn neurones. Neurosci Lett 117:74-80.

Ribeiro-Da-Silva A (1994) Substantia gelatinosa of spinal cord. In: The rat nervous system (Paxinos G, ed). New York: Academic.

Ribeiro-Da-Silva A (1995) Ultrastructural features of the colocalization of calcitonin gene related peptide with substance $\mathrm{P}$ or somatostatin in the dorsal horn of the spinal cord. Can J Physiol Pharmacol 73:940-944.

Ribeiro-Da-Silva A, Coimbra A (1982) Two types of synaptic glomeruli and their distribution in laminae I-III of the rat spinal cord. J Comp Neurol 209:176-186.

Ribeiro-Da-Silva A, Tagari P, Cuello AC (1989) Morphological characterization of substance P-like immunoreactive glomeruli in the superficial dorsal horn of the rat spinal cord and trigeminal subnucleus caudalis: a quantitative study. J Comp Neurol 281:497-515. 
Rusin KI, Bleakman D, Chard PS, Randic M, Miller RJ (1993) Tachykinins potentiate $N$-methyl-D-Aspartate responses in acutely isolated neurons from the dorsal horn. J Neurochem 60:952-960.

Sakurada T, Manome Y, Tan-No K, Sakurada S, Onba M, Kisara K, Terenius L (1993) A selective and extremely potent antagonist of the neurokinin-1 receptor. Regul Pept 46:326-328.

Schouenborg J, Sjölund BH (1986) First-order nociceptors in the rat dorsal horn are blocked by an amino acid antagonist. Brain Res 379:394-398.

Schuman EM, Madison DV (1994) Nitric oxide and synaptic function. Annu Rev Neurosci 17:153-183.

Spike RC, Todd AJ (1992) Ultrastructural and immunocytochemical study of lamina II islet cells in rat spinal dorsal horn. J Comp Neurol 323:359-369.

Takano K, Stanfield PR, Nakajima S, Nakajima Y (1995) Protein kinase $\mathrm{C}$-mediated inhibition of an inward rectifier potassium channel by substance P in nucleus basalis neurons. Neuron 14:999-1008.

Todd AJ, Lewis SG (1986) The morphology of Golgi-stained neurons in lamina II of the rat spinal cord. J Anat 149:113-119.

Tölle TR, Berthele A, Zieglgänsberger W, Seeburg PH, Wisden W (1993) The differential expression of 16NMDA and non-NMDA receptor subunits in the rat spinal cord and in periaqueductal gray. J Neurosci 13:5009-5028.

Tölle R, Berthele A, Laurie DJ, Seeburg PH, Zieglgänsberger W (1995) Cellular and subcellular distribution of NMDAR1 splice variant mRNA in the rat lumbar spinal cord. Eur J Neurosci 7:1235-1244.

Traub RJ, Allen B, Humphrey E, Ruda MA (1990) Analysis of calcitonin gene-related peptide-like immunoreactivity in the cat dorsal spinal cord and dorsal root ganglia provide evidence for a multisegmental projection of nociceptive C-fiber primary afferents. J Comp Neurol 302:562-572.

Traub RJ, Solodkin A, Gebhart GF (1994a) NADPH-diaphorase histochemistry provides evidence for a bilateral, somatotopically inappropriate response to unilateral hindpaw inflammation in the rat. Brain Res 647:113-123.

Traub RJ, Solodkin A, Meller ST, Gebhart GF (1994b) Spinal cord NADPH-diaphorase histochemical staining but not nitric oxide synthase immunoreactivity increases following carrageenan-produced hindpaw inflammation in the rat. Brain Res 668:204-210.
Ueda M, Kuraishi Y, Sugimoto K, Satoh M (1994) Evidence that glutamate is released from capsaicin-sensitive primary afferent fibers in rats: Study with on-line continuous monitoring of glutamate. Neurosci Res 20:231-237.

Valtschanoff JG, Weinberg RJ, Rustioni A (1992) NADPH diaphorase in the spinal cord of rats. J Comp Neurol 321:209-222.

Valtschanoff JG, Phend KD, Bernardi PS, Weinberg RJ, Rustioni A (1994) Amino acid immunocytochemistry of primary afferent terminals in the rat dorsal horn. J Comp Neurol 346:237-252.

Vincent SR (1995) Localization of nitric oxide neurons in the central nervous system. In: Nitric oxide in the nervous system (Vincent SR, ed), pp 83-102. New York: Academic.

Vizzard MA, Erdman SL, Erickson VL, Stewart RJ, Roppolo JR, De Groat WC (1994a) Localization of NADPH diaphorase in the lumbosacral spinal cord and dorsal root ganglia of the cat. J Comp Neurol 339:62-75.

Vizzard MA, Erdman SL, Förstermann U, De Groat WC (1994b) Ontogeny of nitric oxide synthase in the lumbosacral spinal cord of the neonatal rat. Dev Brain Res 81:201-217.

Vizzard MA, Erdman SL, De Groa WC (1995) Increased expression of neuronal nitric oxide synthase (NOS) in visceral neurons after nerve injury. J Neurosci 15:4033-4045.

Wiertelak EP, Furness LE, Watkins LR, Maier SF (1994) Illnessinduced hyperalgesia is mediated by a spinal NMDA-nitric oxide cascade. Brain Res 664:9-16.

Willis Jr WD, Coggeshall RE (1991) Sensory mechanisms of the spinal cord. New York: Plenum.

Wood PL (1995) Nitric oxide and excitatory amino acid-coupled signal transduction in the cerebellum and hippocampus. In: Nitric oxide in the nervous system (Vincent SR, ed), pp 103-124. New York: Academic.

Yajiri Y, Yoshimura M, Okamoto M, Takahashi H, Higashi H (1997) A novel slow excitatory postsynaptic current in substantia gelatinosa neurons of the rat spinal cord in vitro. Neuroscience 76:673-688.

Zhuo M, Small SA, Kandell ER, Hawkins RD (1993) Nitric oxide and carbon monoxide produce long-term enhancement of synaptic transmission in the hippocampus by an activity-dependent mechanism. Science 260:1946-1949. 